\title{
Behandlingsbegrensning på operasjonsstuen?
}

\author{
Når man under en akutt operasjon innser at pasienten ikke kan kureres og har svært kort forventet levetid, \\ reises viktige spørsmål om avslutning av behandling. Vi drøfter her kliniske og etiske aspekter ved en slik \\ situasjon, særlig om det bør være et mål at pasienten får anledning til å gjenvinne bevisstheten.
}

$\AA$ avslutte livsforlengende behandling som enten er nytteløs eller bare forlenger en døende pasients lidelse, vurderes av de fleste ikke bare som klinisk og etisk akseptabelt, men i mange tilfeller som det eneste riktige i begge henseende. Når livsforlengende behandling avsluttes, kan man videreføre den palliative. Slik behandlingsbegrensning innebærer at man fortsetter å lindre pasientens somatiske, psykiske, sosiale og åndelig/eksistensielle plager frem til dødstidspunktet (1). Retningslinjer for hvordan man bør gå frem er gitt av Helsedirektoratet $\mathrm{i}$ en nasjonal veileder fra 2009 (2)

Men det finnes situasjoner der det kan være vanskelig å vurdere om pasienten er tjent med behandlingsbegrensning. Det kan også være vanskelig å vite hvordan man bør begrense behandlingen.

\section{Den kliniske situasjonen}

Når pasienter blir akutt alvorlig syke på grunn av en kirurgisk tilstand, vurderes det noen ganger som riktig å gjøre et forsøk på årsaksrettet kirurgisk behandling selv om pasienten er alvorlig påvirket og i betydelig nedsatt allmenntilstand. For eksempel vil iskemi av store mengder tarm føre til alvorlig svikt i flere organsystemer. Fordi kirurgisk behandling da vil være pasientens eneste mulighet for å overleve den akutte tilstanden, vil man ofte velge å operere slike pasienter dersom det er et visst håp om at tilstanden kan korrigeres kirurgisk og at pasienten vil tåle det operative inngrepet og narkosen.

Imidlertid vil man etter start av operasjonen noen ganger innse at tilstanden er for alvorlig til at den kan kureres. Når kirurgen rister på hodet og sier at «her kan vi ikke gjøre noe, det er bare å lukke buken», reiser dette viktige etiske spørsmål om neste skritt. Man vet at pasienten ikke kan overleve sykdomsepisoden, men det er vanskelig å vurdere om døden kan forventes i løpet av en knapp time eller et halvt til ett døgn.

\section{Kliniske handlingsalternativer}

I teorien foreligger det i en slik situasjon følgende handlingsalternativer:

- Umiddelbart avslutte all medikamentell behandling og ekstubere pasienten
- Forsøke å avslutte narkosen på vanlig måte, det vil si å gi nødvendig vasoaktiv behandling og vanlig smertebehandling, samtidig som man forsøker å vekke pasienten fra narkosen ved å stanse tilførselen av anestesimidler

- Intensivbehandle pasienten med det mål å forlenge livet lengst mulig

Det første alternativet, der man ekstuberer og avslutter eventuell vasoaktiv behandling mens pasienten er i narkose, vil gi ganske umiddelbar død som følge av sirkulatorisk kollaps og/eller kvelning.

Det andre alternativet vil innebære at man enten kommer i en situasjon der pasienten våkner og puster, eller at pasienten til tross for eliminering av narkosemidlene ikke våkner og/eller ikke gjenvinner egenrespirasjon. I begge tilfeller vil pasienten ofte være avhengig av vasoaktivt støttende medikamenter for å unngå sirkulatorisk kollaps. Dersom pasienten våkner og gjenvinner egenrespirasjon, vil man forsøke å legge til rette for at han kan få tilbringe den siste tiden sammen med eventuelle nære pårørende. Det må da vurderes hvor lenge det er tjenlig å opprettholde vasoaktivt støttende behandling. Hvis pasienten ikke våkner og/eller ikke gjenvinner egenrespirasjon, blir alternativene å ekstubere og/eller avslutte vasoaktiv behandling på operasjonsstuen eller å ta pasienten til en intensivavdeling for optimalisering, $\mathrm{i}$ håp om at han kan gjenvinne bevissthet og eventuelt respirasjon.

Det tredje alternativet vil innebære å transportere pasienten intubert og sedert med pågående pressorbehandling til intensivavdeling og der iverksette all tilgjengelig behandling for å utsette døden lengst mulig. Man vil etter hvert prøve å vekke pasienten når de største avvikene er (forsøkt) korrigert.

\section{Vurderinger i lys \\ av den nasjonale veilederen}

Veilederen gir en rekke føringer som også er relevante når det gjelder å ivareta pasientens beste i den situasjonen vi drøfter her (2):

- Eventuell fortsatt behandling må ha en positiv virkning som oppveier plagene forbundet med behandlingen/sykdommen
- Det bør foreligge enighet om beslutningen om behandlingsbegrensning $i$ behandlingsteamet

- Dersom pasienten mangler samtykkekompetanse skal man innhente informasjon fra pårørende (jf. pasientrettighetsloven $\S$ 4-6)

- Lindrende behandling skal fortsette selv om livsforlengende behandling begrenses eller avsluttes

Én føring passer imidlertid ikke i denne situasjonen. Ifølge veilederen bør vasoaktive medikamenter "seponeres da deres indikasjon er å understøtte det kardiovaskulære systemet temporært til det gjenvinner sin funksjon» (2). Dersom man seponerer pressormedikamenter i den aktuelle situasjonen, vil det ofte føre til umiddelbar sirkulatorisk kollaps. Nedenfor begrunner vi hvorfor dette vil være etisk betenkelig.

\section{Etiske betraktninger}

De etiske betraktningene i situasjonen angår hovedsakelig to forhold: Hvorvidt noen av handlingsalternativene innebærer å utføre eutanasi eller ufrivillig medisinsk drap, og hva som taler for å velge handlingsalternativer som har som mål å vekke pasienten.

Eutanasi er definert internasjonalt som en leges drap på pasienten ved injeksjon eller infusjon av medikamenter på pasientens frivillige forespørsel $(1,3)$. Ettersom pasienten er bevisstløs og derfor ikke kan fremsette noen forespørsel og det heller ikke med hensikt settes dødsfremkallende medikamenter, kan det her følgelig ikke være tale om eutanasi. Dersom en lege bruker medisiner for å ta livet av en pasient som ikke er samtykkekompetent, er det snakk om et ikke-frivillig medisinsk drap $(1,3)$. Foreligger det samtykkekompetanse, men ingen forespørsel, er det medikamentelle drapet ufrivillig $(1,3)$.

Pasienter i narkose innehar samtykkekompetanse - selv om denne midlertidig er satt ut av spill. Det forste handlingsalternativet umiddelbart avslutte respiratorbehandling og vasoaktivt støttende medikamenter hos en pasient som fremdeles er i narkose - har en overflatelikhet med ufrivillig medisinsk drap. Forskjellen er at det ikke gis dødbringende medisiner for å oppnå prematur $\mathrm{død}$. 


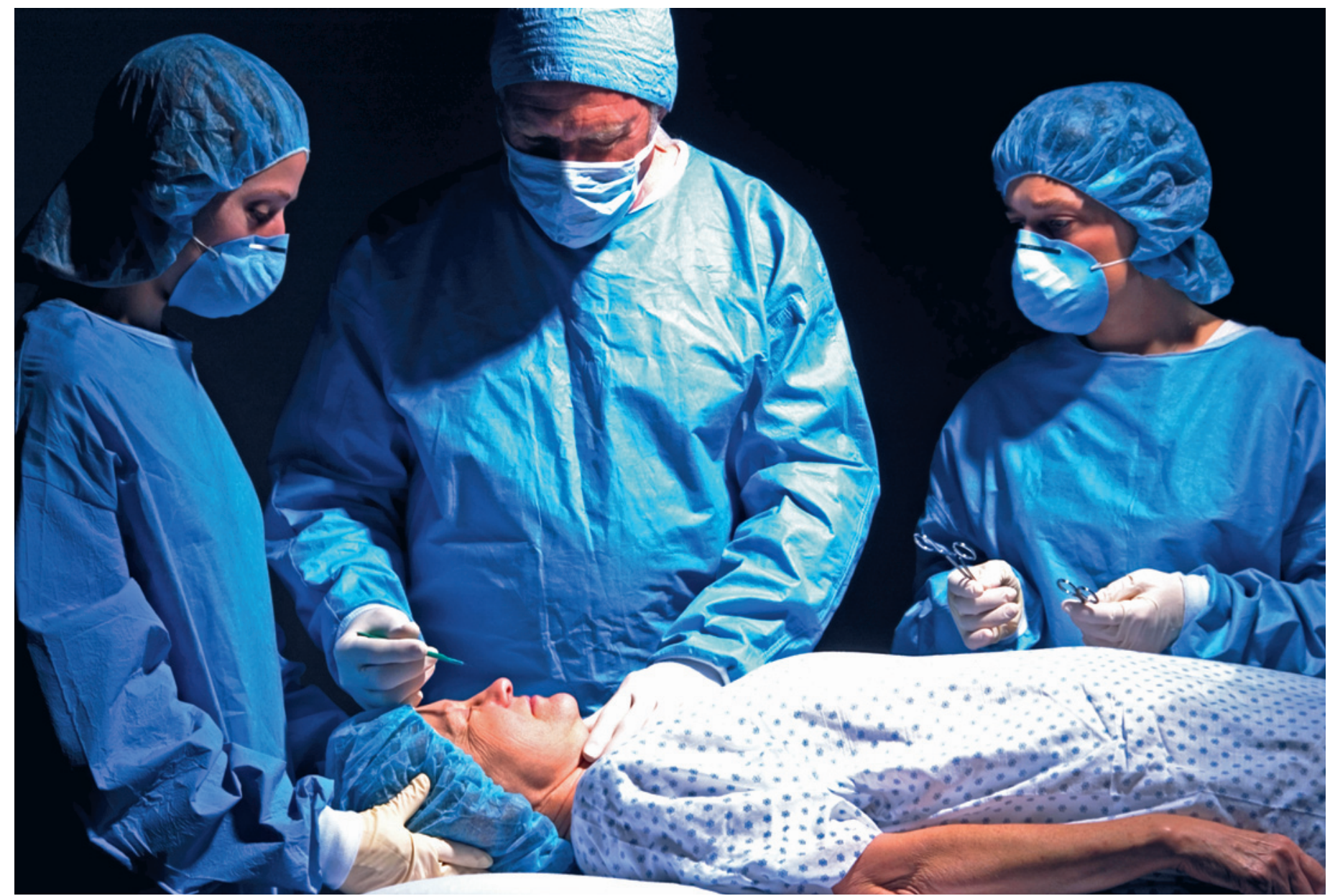

Illustrasjonsfoto thinkstock

Likevel kan det innvendes at man her intensjonalt fremprovoserer pasientens død siden han som ledd i narkosen allerede har fått medikamenter som vil være dødbringende dersom respirasjon og sirkulasjon ikke understøttes. Noen vil derav kanskje betegne handlingen som ufrivillig medisinsk drap "på et annet nivå», nemlig gjennom behandlingsunnlatelse (ikke behandlingsbegrensning) - med andre ord en unnlatelsessynd i ordets rette og mest dramatiske forstand.

Uten å ha forsøkt å vekke vet man ikke om pasienten har evne til å gjenvinne bevissthet og/eller respirasjon. Derimot vet man at det å skru av respiratoren hos en pasient $\mathrm{i}$ dyp narkose, vil føre til rask kvelningsdød, og at det å bråseponere pressormedikamenter vil medføre sirkulatorisk kollaps.

Selv om dette rent faktisk er forskjellig fra å injisere dødbringende medikamenter, er intensjonen og utfallet det samme: Pasientens umiddelbare død. Spørsmålet er da om dette er en forskjell som utgjør en forskjell - altså om det er en etisk relevant forskjell.

\section{Argumenter mot vekking}

Det finnes i hovedsak to argumenter mot å forsøke å vekke:
- Det kan tenkes at pasienten har sterke smerter

- Det er mer ressurskrevende enn å avslutte raskest mulig - særlig dersom man skal gjøre forsøk på å optimalisere pasientens tilstand

Muligheten for sterke smerter er imidlertid ikke noen grunn til ikke å forsøke å vekke. Dersom pasienten ved vekking har intense smerter, vil man kunne lindre disse. Siste utvei er å sedere pasienten på ny. Dette tilsvarer anbefalt prosedyre ved lindrende sedering til døende i andre situasjoner (4). I en slik situasjon blir det derimot naturlig å vurdere å avslutte vasoaktivt støttende behandling. For uten utsikter til å kunne vekke vil fortsatt pressorbehandling kun medføre en forlengelse av dødsprosessen hos en bevisstløs.

\section{«lkke vekke» $\mathrm{i}$ lys av etisk teori}

Hvorvidt handlingen «ikke vekke» kan forsvares med hensynet til å spare ressurser og bruke disse til andre pasienters fordel eksempelvis dem som kan kureres - avhenger av hvilket etisk prinsipp eller hvilken etisk teori man legger til grunn. Ved en utilitaristisk (nyttefilosofisk) tilnærming virker det som svaret er ja, ettersom «størst mulig nytte/lykke for flest mulig» er den overordnede norm (5).
Pliktetisk sett er nok svaret nei. Den viktigste tenkeren innen denne tradisjonen er Immanuel Kant (1724-1804). Ifølge ham sier vår egen moralske fornuft at hvert enkelt menneske har «uendelig verdi» og «verdighet» og at det følgelig «ikke har noen pris». Det er dermed galt å bruke mennesker som rene midler til andres tilfredsstillelse, det er å krenke dem som «formål i seg selv» (6).

Dersom vi tar utgangspunkt i Beauchamp \& Childress' fire prinsipper for helseetikk (7) - velgjørenhet, ikke skade, respekt for autonomi, rettferdighet - later det til at handlingen bryter med de tre første. Hvorvidt rettferdighetshensyn kan begrunne den, er mer åpent. Men ut fra en total avveining mellom prinsippene, og særlig veid mot autonomiprisippet (8), synes svaret likevel å være at ressursbesparelse ikke er en etisk akseptabel grunn til å la være å forsøke å vekke pasienten, forutsatt at det er grunn til å tro at forsøket er til hans beste.

\section{Argumenter for å vekke}

Det er flere vektige argumenter for å fors $ø$ ke å vekke pasienten. Vedkommende får mulighet til å kommunisere med pårørende, inkludert avskjed, trøst og forsoning, samt til å samtale med prest eller liknende. Dessuten kan han uttrykke sin siste vilje gjennom et 
nødtestament, jf. arveloven $\S 51$. Dette kan også være viktig for de pårørende, som skal leve videre. Et møte med en prest eller tilsvarende kan være viktig for enkelte og kan inneholde sjelesorg, skriftemål, forbønn, sykesalving eller nattverd. Siden en våken periode for pasienten kan bli svært kort, bør man allerede før han våkner vurdere om prest eller en annen åndelig veileder bør tilkalles. Pårørende vil ofte kunne gi svar på om dette vil være viktig for pasienten, men det vil også være til nytte å ha gjort en åndelig anamnese på forhånd (9).

I de tilfellene pasienten ikke våkner ved avslutning av operasjonen, bør man bruke tid og ressurser på å korrigere større avvik, i håp om at han vil våkne. Det mest aktuelle eksemplet er pasienter som er hypoterme ved avslutning av operasjonen. På bakgrunn av argumentene over kan det forsvares å respiratorbehandle noen timer samtidig som man varmer pasienten og gir pressorbehandling. Dersom slik optimalisering fører til at pasienten kan få noen siste våkne timer der symptomene er godt lindret, vil det være etisk galt å trekke tilbake all behandling på et tidligere tidspunkt.

Kortvarig intensivbehandling vil være riktig for å korrigere store avvik som relativt enkelt kan korrigeres eller for å vinne tid til pårørende når frem dersom det ikke innebærer uforholdsmessig store plager for pasienten - jf. prinsippet om velgjørenhet $(7,8)$. På den annen side vil en lengre full intensivbehandling for å forlenge livet maksimalt være galt ettersom den i realiteten kun vil forlenge dødsprosessen. Det ville bety en unødvendig belastning for pasienten og representert meningsløs ressursbruk. Man ville med andre ord bryte prinsippene om ikke å skade og om rettferdighet $(7,8)$.

Hvis pasienten derimot har en forventet levetid på dager til uker, vil noen dagers intensivbehandling være riktig for å forsøke å gi ham en siste god tid med gjenvunnet bevissthet.

En grundig preoperativ samtale vil kunne gjøre det enklere å ivareta pasientens vilje dersom noe utforutsett skulle skje under operasjonen. Som veilederen formulerer det: «Respekt for pasientens autonomi og integritet forutsetter god og hensynsfull kommunikasjon med pasienten og/eller pårørende. Dette inkluderer blant annet at helsepersonell må informere pasienten så godt at han/hun blir i stand til å treffe de valg som er riktige for ham/henne» (2).

\section{Konklusjon}

Det finnes flere sterke argumenter for at noen våkne timer på slutten av livet kan være av stor betydning for både pasient og pårørende. Autonomi er en kjerneverdi i medisinsk behandling og i medisinsk etikk $(2,7,8)$. Bare en bevisst pasient kan handle autonomt, og det bør derfor prioriteres høyt å gi pasienten anledning til å gjenvinne denne evnen - selv om den forventede levetid er svært kort.

Det innebærer at rådet som gis i veilederen om at man bør trekke tilbake vasoaktivt støttende medikamenter, ikke passer i denne situasjonen (2). Dette er trolig uttrykk for at veilederen ikke har tatt, og rimeligvis vanskelig kan ta, høyde for alle kliniske scenarioer der behandlingsbegrensning vil være relevant.

\section{Olav Magnus S. Fredheim}

olav.m.fredheim@ntnu.no

Nasjonal kompetansetjeneste

for sammensatte lidelser

og

Klinikk for anestesi og akuttmedisin

St. Olavs hospital

og

Forskningsgruppe smerte og palliasjon

Institutt for sirkulasjon og bildediagnostikk Det medisinske fakultet

Norges teknisk-naturvitenskapelige universitet

\section{Lars Johan Materstvedt}

Filosofisk institutt

Det humanistiske fakultet

Norges teknisk-naturvitenskapelige universitet

Olav Magnus S. Fredheim (f. 1979) er ph.d. i smertemedisin. Han er lege i spesialisering i anestesiologi ved St. Olavs hospital og forsker ved Nasjonal kompetansetjeneste for sammensatte lidelser og ved Institutt for sirkulasjon og bildediagnostikk, Det medisinske fakultet, Norges teknisk-naturvitenskapelige universitet. Forfatter har fylt ut ICMJE-skjemaet og oppgir ingen interessekonflikter.
Lars Johan Materstvedt (f. 1960) er dr.art. og professor ved Filosofisk institutt, Det humanistiske fakultet, Norges teknisk-naturvitenskapelige universitet. Han har vært forsker i Kreftforeningen og leder av The Ethics Task Force on Palliative Care and Euthanasia, European Association for Palliative Care (EAPC).

Forfatter har fylt ut ICMJE-skjemaet og oppgir ingen interessekonflikter.

Litteratur

1. Materstvedt LJ, Førde R. Fra aktiv og passiv dødshjelp til eutanasi og behandlingsbegrensning. Tidsskr Nor Legeforen 2011; 131: 2138-40.

2. Nasjonal veileder for beslutningsprosesser for begrensning av livsforlengende behandling hos alvorlig syke og døende. Oslo: Helsedirektoratet, 2009. www.helsedirektoratet.no/publikasjoner/ nasjonal-veileder-for-beslutningsprosesser-forbegrensning-av-livsforlengende-behandling-hosalvorlig-syke-og-doende/Sider/default.aspx (28.3.2012)

3. Griffiths J, Weyers H, Adams M. red. Euthanasia and law in Europe. Oxford: Hart Publishing, 2008.

4. Rådet for legeetikk. Retningslinjer for lindrende sedering til døende. Oslo: Den norske legeforening, 2001. www.legeforeningen.no/spesial/ Norsk-forening-for-palliativ-medisin/Veiledere/ retningslinjer-for-lindrende-sedering-til-doende/ (28.3.2012).

5. Carson SG, Kosberg N. Etikk. Teori og praksis. Oslo: Cappelen Damm Akademisk, 2011

6. Kant I. Grunnlegging av moralens metafysikk I: Storheim E, red. Moral, politikk og historie. Oslo: Universitetsforlaget, 1983: 11-76.

7. Beauchamp TL, Childress JF. Principles of biomedical ethics. 6. utg. Oxford: Oxford University Press, 2008.

8. Gillon R. Ethics needs principles - four can encompass the rest - and respect for autonomy should be «first among equals». J Med Ethics 2003; 29: 307-12.

9. Magelssen M, Fredheim OM. En åndelig dimensjon er viktig for mange pasienter. Tidsskr Nor Legeforen 2011: 131: 138-40.

Mottatt 2.1. 2012, første revisjon innsendt 2.4. 2012, godkjent 12.4. 2012. Medisinsk redaktør Are Brean. 